\title{
ANALYSIS OF THE GEOMETRY OF SURFACE DEFORMATIONS CAUSED BY INDUCED TREMORS IN THE AREA OF UNDERGROUND COPPER MINING
}

\author{
K.Owczarz ${ }^{1 *}$, J. Blachowski ${ }^{1}$ \\ ${ }^{1}$ Dept. of Mining and Geodesy, Wroclaw University of Science and Technology, Stanisława Wyspiańskiego 27 Street, 50-370 \\ Wrocław, Poland - (karolina.owczarz, jan.blachowski)@pwr.edu.pl
}

KEY WORDS: DInSAR, induced seismicity, underground copper mining, ground displacement, geometry, Poland

\begin{abstract}
:
Induced seismicity by human operations such as mining is usually unpredictable due to the sudden and unexpected character of this phenomenon. The effects of seismic events on the surface, i.e. ground deformation had been difficult to measure with traditional geodetic methods, which are based on discrete point observations and are carried out at temporal intervals and in fixed locations (e.g. levelling lines). Development of radar remote sensing (InSAR) techniques and proliferation of open satellite radar data such as Sentinel1 mission provides means that can now be successfully applied to investigate areas and ground movements affected by seismicity induced by mining. In this paper four induced seismic events with magnitudes from 4.5 to 4.8 that occurred between 16 December 2016 and 15 September 2018 in the Rudna underground copper mine area in SW Poland have been investigated with differential satellite radar interferometry (DInSAR). Based on the results of processing of 37 pairs of Sentinel-1 data captured before and after each of these events, deformation areas have been spatially localised and vertical displacement and extent of deformation have been calculated. The mean maximum vertical displacements range from $-70 \mathrm{~mm}$ for the 4.5 magnitude tremor to $-94 \mathrm{~mm}$ for the 4.8 magnitude event. Whereas, mean extent ranges from $1.5 \mathrm{~km}$ to $1.9 \mathrm{~km}$ in the W-E direction and from $1.8 \mathrm{~km}$ to $2.1 \mathrm{~km}$ in the N-S direction. A linear relation between magnitude of induced tremor and increase in vertical displacement and extent of the ground deformation has been established. Moreover, the results of this study indicate that InSAR is adequately accurate technique to analyse ground displacements caused by mining induced tremors and provides continuous field data on the geometry of the resulting deformation areas.
\end{abstract}

\section{INTRODUCTION}

Induced seismicity is a dynamic phenomenon that can be triggered off during increased anthropogenic activity in the rock mass and can appear in aseismic areas. It is connected with mining of solid minerals, extraction of conventional and unconventional hydrocarbons, underground storage of liquids and gases, production of geothermal energy and construction of retention reservoirs (Fougler, 2018) as these engineering operations change the natural stress distribution in the rock mass. In case of underground mining the occurrence of induced seismicity may further be affected by depth of mining, mining system used and geological and tectonic conditions. Induced and natural seismicity cause similar form of surface vibrations. The main differences between mining tremors (induced seismicity) and natural earthquakes are, the depth and energy of the event (magnitude). However, Zembaty $(2004,2010)$ in his research presented quantitative and qualitative differences in the context of surface effects. Mining-induced tremors cause faster movement of the rock mass and accelerated compaction of above lying rock formations in these areas. In terms of the impact on the surface, two types of induced mining tremors are distinguished: weak energy shocks that donot cause surface deformations, and shocks exceeding a certain energy level, which produce deformation of the ground surface (Kaszowska, 2007). Due to the unpredictable nature and strength of induced seismic events, their occurrence pose a threat to mining operations, technical infrastructures on the ground and also may affect human safety (Ellsworth, 2013). In the period from January 2016 to December 2019246 seismic events with a magnitude equal or greater than 2.0 were registered in Poland, among these 120 with magnitudes equal or greater than 3.0, and 22 with magnitudes equal or greater than 4.0 (https://www.emsc-csem.org/). Majority of these tremors occurred in copper and hard coal underground mining regions. Traditionally surveying of the effects of induced seismic tremors on the ground's surface was carried out using levelling and/or GNSS measurements (Popiołek et al., 2001; Szczerbowski and Jura, 2015). However, the practical use of classical geodetic techniques is limited due to the fact of the sudden and unexpected character of induced seismicity in mining areas. The practice of geodetic surveying in mining areas relies on periodic measurements of the same leveling lines. Therefore, the probability of measuring area of induced shock before and after it occurred is very small. A breakthrough was brought by the advent radar remote sensing technologies such as satellite radar interferometry (InSAR) that provides the ability to observe the geometrical state of the ground prior and after the seismic event with temporal resolution of several days.

Recent years have brought onset and development of studies focusing on the phenomenon of mining terrain deformations related to induced seismicity. This has been due to the proliferation of data acquired by commercial and open access satellite radar mission used in Earth monitoring programmes. Numerous studies utilizing satellite radar interferometry for monitoring of surface deformations caused by hydraulic fracturing have been published, these include (Barba et al., 2016; Thorpe, 2017; Albano et al., 2017; Loesh and Sagan, 2018; Barnhart et al., 2018). In addition, similar research has been conducted in case of to hard coal mining (Krawczyk and

\footnotetext{
* Corresponding author
} 
Grzybek, 2018; Rudziński et al., 2019 ) and copper mining (Graniczny et al., 2017; Milczarek, 2019; Hejmanowski et al., 2019). Results of all of these studies indicate that various methods of satellite radar interferometry are suitable for detecting surface deformations caused by induced seismicity measured in the Line of Sight (LOS) of the satellite. These studies have not so far been aimed at statistical analysis of the geometry of deformations caused by seismicity induced by underground mining.

The aim of this research has been first to calculate surface deformations caused by a number of seismic events induced by underground mining and then to analyse statistically the principal geometrical parameters of the resulting deformation areas in relation to the magnitude of the seismic events.

The paper is organized as follows, after the introduction section with state of research and aim of the research, the basic information on the location, topography, geology and tectonics as well as mining and induced seismicity in the study area has been provided. The Data and methods section contains description of the input data used and the DInSAR calculation method; In the Results and discussion section the results are presented statistically and graphically and analysed. The Conclusions summarize the main findings of this study.

\section{STUDY AREA}

\subsection{Location and topography}

The Rudna mine is located in the south west part of Poland in the Lower Silesia region (voivodeship) and is one of several underground copper mines operated by the KGHM Polish Copper S.A. company in the area. The spatial extent of the Rudna mining ground is limited by the following geographical coordinates: $51^{0} 34^{\prime} 15^{\prime \prime} \mathrm{N}, \quad 51^{\circ} 28^{\prime} 15^{\prime \prime} \mathrm{S}$ and $16^{\circ} 02^{\prime} 10^{\prime \prime} \mathrm{W}$, $16^{0} 14^{\prime} 30^{\prime \prime} \mathrm{E}$ and covers an area of approx. $77.8 \mathrm{~km}^{2}$. Location of the mining area has been shown in Figure 1. Topography of the region was shaped by the Mindel and Riss glaciations and the subsequent processes obscuring the post-glacial landforms. The present-day shape of the terrain is composed predominately of plains that locally are varied by wide and low hills of glacial origin, and cut by shallow and wide valleys, as well as flat and extensive depressions (Kiresnowski and Petecki, 2017).

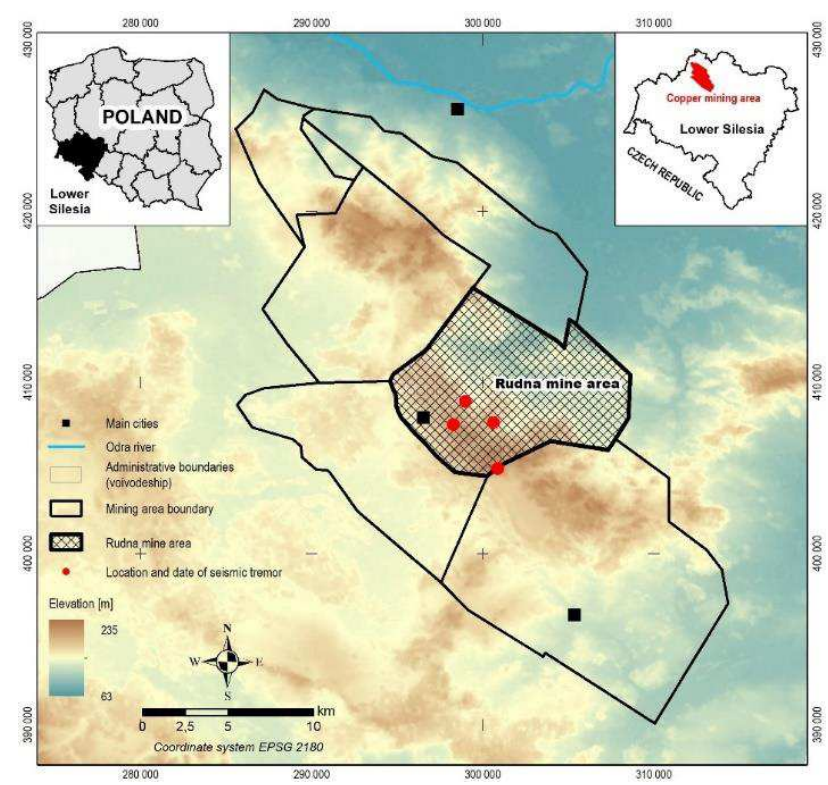

Figure 1. Location of the analysed seismic events in relation to Rudna mining ground boundaries
The land use structure is dominated by arable land and grassland (approx. 60\%), forests (approx. 30\%), built-up areas (7.6\%) and $2.4 \%$ by other forms (www.pig.gov.pl).

\subsection{Geology and tectonics}

The depth of deposition of the copper orebody in the Rudna deposit ranges from $844 \mathrm{~m}$ up to $1250 \mathrm{~m}$. The deposit consists of sandstone ores (approx. $80 \%$ of resources), carbonate ores (approx. 15\%) and copper-bearing shale constituting only 5\% of total deposit mass (www.kghm.com). The deposit formations are located in the Fore-sudetic Monocline geological unit and extend in the NW-SE direction in accordance with the direction of the boundary of the monocline with the Fore-sudetic Block, another geological unit in the south. The copper orebody dips in the NE direction at an angle of 1 up to 6 degrees (Sudot, 2009). The main directions of dip and extent change in tectonic dislocation zones and in region of elevated roof of the sandstone layers. The southwestern part of the Rudna mining area is intersected by faults running east and north-east and belonging to the Biedrzychowa fault line. The downthrow of these faults in the north-west direction range from $40 \mathrm{~m}$ to $140 \mathrm{~m}$. To the west a syncline with depth of $20 \mathrm{~m}$ to $30 \mathrm{~m}$ and parallel to the Biedrzychowa fault line is located. In addition, in the southern part of the deposit a number of faults produce horsts and throughs with amplitudes ranging from several to $30 \mathrm{~m}$ (Butra, 2017).

\subsection{Mining and induced seismicity}

The Rudna copper mine began operation in 1974 and is the largest underground copper mine in Europe and one of the largest of such kind in the world. The thickness of the copper ore deposit reaches over a dozen meters with average thickness of over $4 \mathrm{~m}$. The mineral deposit was documented in the abovementioned sedimentary rock formations and belongs to the so-called stratoidal type. It is mined in three areas that are accessed through 10 shafts with depths ranging from 941 to 1244 meters below surface level. The company uses room and pillar mining system. The ore is mined by means of blasting technique, both in the phase of access, preparatory and operational works. The ore is transported from the mining faces using loaders and haulage trucks to crushers and further horizontal transport to the shafts takes place through conveyor belts (KGHM internal team, 2012). Because of the local geological and tectonic settings and depth of mining the Rudna mine is the most susceptible to induced seismic events among the copper operations in the area.

The mining region is one of the few areas of induced seismicity in Poland. Several dozen such seismic tremors occur in this area due to the underground exploitation of copper orebody annually. In total, 246 seismic events of magnitude 2.0 or above were registered there from January 2016 to December 2019. In most cases the energy released is low and the shocks are unnoticed by local population and donot pose threat to surface infrastructure or mining operation. However, each year several tremors have magnitudes of 4.0 or above and these events can cause surface deformations, damage infrastructure and threaten safety or lives of mine workers. The most serious one recently occurred on the 29 November 2016 and caused the death of 8 miners. Another one of 29 January 2019 caused evacuation of 32 miners. In this paper four induced shocks with magnitude of above 4.0 have been analysed. 


\section{DATA AND METHODS}

The analysed seismic events occurred between 16 December 2016 and 15 September 2018. Locations of these events (X, Y coordinates) were obtained from the Rudna copper mine seismic monitoring network. The deformations were calculated using differential satellite radar interferometry and 64 SLC images acquired by the ESA's Copernicus program Sentinel-1A/B missions. The images were registered for track 73 (ascending orbit) and track 22 (descending orbit). Several sets of image pairs, one acquired before and the second after particular event and for temporal bases ranging from 6 to 24 days were processed. Details of the processed Sentinel-1 satellite data have been given in Table 1.

\begin{tabular}{|c|c|c|c|}
\hline \multirow{2}{*}{$\begin{array}{l}\text { Date } \\
\text { induced } \\
\text { shock }\end{array}$} & \multirow{2}{*}{$\begin{array}{l}\text { Time } \\
\text { interval } \\
\text { [days] }\end{array}$} & \multicolumn{2}{|c|}{ Date of Sentinel-1 satellite imagery } \\
\hline & & $\begin{array}{l}\text { ascending orbit, } \\
73 \text { track }\end{array}$ & $\begin{array}{l}\text { descending orbit, } \\
22 \text { track }\end{array}$ \\
\hline $16 / 12 / 2016$ & 12 & - & $\begin{array}{c}07 / 12 / 2016 \\
19 / 12 / 2016 \\
\end{array}$ \\
\hline \multirow[t]{4}{*}{$07 / 12 / 2017$} & 6 & $\begin{array}{l}05 / 12 / 2017 \\
11 / 12 / 2017\end{array}$ & $\begin{array}{l}02 / 12 / 2017 \\
08 / 12 / 2017\end{array}$ \\
\hline & 12 & $\begin{array}{l}05 / 12 / 2017 \\
17 / 12 / 2017\end{array}$ & $\begin{array}{l}02 / 12 / 2017 \\
14 / 12 / 2017 \\
26 / 11 / 2017 \\
08 / 12 / 2017\end{array}$ \\
\hline & 18 & $\begin{array}{l}05 / 12 / 2017 \\
17 / 12 / 2017\end{array}$ & $\begin{array}{l}08 / 12 / 2017 \\
20 / 11 / 2017\end{array}$ \\
\hline & 24 & $\begin{array}{l}05 / 12 / 2017 \\
29 / 12 / 2017\end{array}$ & $\begin{array}{l}20 / 12 / 2017 \\
26 / 11 / 2017\end{array}$ \\
\hline \multirow[t]{3}{*}{$26 / 12 / 2017$} & 12 & $\begin{array}{l}23 / 12 / 2017 \\
04 / 01 / 2018\end{array}$ & $\begin{array}{l}20 / 12 / 2017 \\
01 / 01 / 2018\end{array}$ \\
\hline & 18 & $\begin{array}{l}11 / 12 / 2017 \\
29 / 12 / 2017\end{array}$ & - \\
\hline & 24 & $\begin{array}{l}05 / 12 / 2017 \\
29 / 12 / 2017\end{array}$ & $\begin{array}{l}08 / 12 / 2017 \\
01 / 01 / 2018 \\
14 / 12 / 2017 \\
07 / 01 / 2018\end{array}$ \\
\hline \multirow[t]{3}{*}{$15 / 09 / 2018$} & 6 & - & $\begin{array}{l}10 / 09 / 2018 \\
16 / 09 / 2018\end{array}$ \\
\hline & 12 & $\begin{array}{l}07 / 09 / 2018 \\
19 / 09 / 2018\end{array}$ & $\begin{array}{l}04 / 09 / 2018 \\
16 / 09 / 2018\end{array}$ \\
\hline & 18 & - & $\begin{array}{l}29 / 08 / 2018 \\
16 / 09 / 2018\end{array}$ \\
\hline
\end{tabular}

Table 1. List of the Sentinel-1 data processed for the four analysed seismic events.

The differential satellite radar interferometry (DInSAR) method was used to determine Line of Sight (LOS) displacements between two satellite images (master and slave). The theory behind this technique has been described among other by (Hooper et al., 2012; Bianchini et al., 2018). The calculations were done in the GMTSAR version 5.4.5 software, which is an open source (GNU General Public License) InSAR processing system designed for users familiar with Generic Mapping Tools (GMT). The general scheme of the procedure using this technique is shown in Figure 2. In the first step, coregistration was performed, to match the pixel geometry of the slave image with the master image. Based on the aligned images, the real interferogram was generated, i.e. the phase difference of the electromagnetic wave, which was recorded before and after the particular seismic event for the same point on earth. The Digital Elevation Model (SRTM) was used to generate a synthesized interferogram that reduced the topographic component. The next step was to calculate the difference between the real interferogram and the synthesized interferogram.

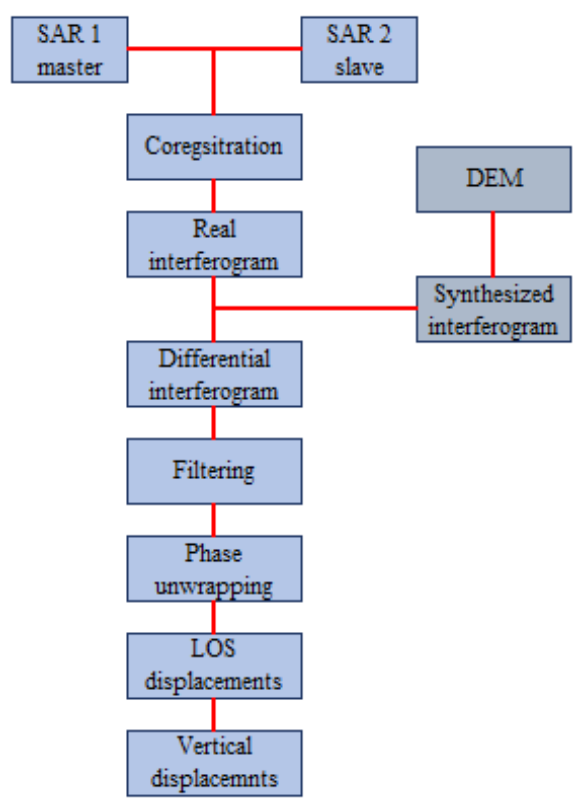

Figure 2. General scheme of the DInSAR processing technique applied in this study

In the result a differential interferogram that contained interferometric bands representing surface displacements corresponding to half the wavelength used by the SAR system (Sentinel-1 $K=5.6 \mathrm{~cm}$ ) was obtained. The differential interferogram was then subjected to a filtering process to eliminate the impact of SAR registration errors and atmospheric errors. The phase unwrapping process consisting of determining the actual phase size enabled the calculation of LOS displacements that were georeferenced. Finally, LOS displacement was converted to vertical displacements using the following relationship (Yastika and Shimizu, 2016):

$$
d_{v}=\frac{d_{L O S}}{\cos \theta}
$$

where

$$
\begin{aligned}
& d_{L O S}-\text { LOS displacement, } \\
& \Theta-\text { look angle }
\end{aligned}
$$

In the result of DInSAR processing, LOS displacement maps, vertical displacement maps and coherence maps were obtained. Example intermediate products, i.e. interferograms for each seismic events have been presented in Appendix A. The results were analyzed in the context of deformation geometry, relationships between the tremors' magnitude and the resulting value of vertical displacements, as well as spatial extent of the resulting deformation. Descriptive statistics for terrain deformations were prepared and discussed in the next part.

\section{RESULTS AND DISCUSSION}

In total, 37 pairs of images were processed, 9 pairs for seismic event of 16 December 2016, 10 pairs for seismic event of 7 December 2017, 10 pairs for the one of 26 December 2017, and 8 pairs for seismic event of 15 September 2018. The temporal baseline between subsequent images ranged from 6 to 24 days. In case of 16 pairs that were processed no valid results of displacements were obtained, due to low coherence. For the remaining 21 pairs clear and distinct deformation areas were 
identified. These were used to calculate statistics describing mean extent and mean maximum subsidence for each case and to analyse relation between magnitude and above mentioned geometrical characteristics. The statistics, maximum, minimum, mean values of maximum subsidence and extent in N-S and $\mathrm{W}-\mathrm{E}$ directions for each seismic event have been presented in Table 2 (results for pairs of descending and ascending imagery), and graphs in figures 3 to 5. The "-“" sign in Table 2 indicates subsidence. Mean coherence values for pixels within the deformation areas ranged from 0.29 to 0.40 .

\begin{tabular}{|l|c|c|c|c|}
\hline $\begin{array}{l}\text { Date of } \\
\text { seismic } \\
\text { event }\end{array}$ & $\mathbf{1 6 / 1 2 / 2 0 1 6}$ & $\mathbf{0 7 / 1 2 / 2 0 1 7}$ & $\mathbf{2 6 / 1 2 / 2 0 1 7}$ & $\mathbf{1 5 / 0 9 / 2 0 1 8}$ \\
\hline Magnitude & 4.5 & 4.7 & 4.8 & 4.6 \\
\hline $\begin{array}{l}\text { min. } \\
\text { displacement } \\
\text { [mm] }\end{array}$ & -70 & -59 & -91 & -66 \\
\hline $\begin{array}{l}\text { max. } \\
\text { displacement } \\
\text { [mm] }\end{array}$ & -70 & -101 & -96 & -81 \\
\hline $\begin{array}{l}\text { mean } \\
\text { displacement } \\
\text { [mm] }\end{array}$ & -70 & -83 & -94 & -77 \\
\hline $\begin{array}{l}\text { min. W-E } \\
\text { extent [km] }\end{array}$ & 1.5 & 1.4 & 1.8 & 1.6 \\
\hline $\begin{array}{l}\text { max. W-E } \\
\text { extent [km] }\end{array}$ & 1.5 & 2.0 & 2.1 & 2.0 \\
\hline $\begin{array}{l}\text { mean W-E } \\
\text { extent [km] }\end{array}$ & 1.5 & 1.8 & 1.9 & 1.8 \\
\hline $\begin{array}{l}\text { min. N-S } \\
\text { extent [km] }\end{array}$ & 1.8 & 1.9 & 1.7 & 1.8 \\
\hline $\begin{array}{l}\text { max. N-S } \\
\text { extent [km] }\end{array}$ & 1.8 & 2.1 & 2.2 & 2.1 \\
\hline $\begin{array}{l}\text { mean N-S } \\
\text { extent [km] }\end{array}$ & 1.8 & 2.0 & 2.1 & 1.9 \\
\hline
\end{tabular}

* "- "indicates subsidence

Table 2. Statistics describing geometry of deformation areas caused by the four analysed seismic events

In order to analyse geometric characteristics of the ground deformations resulting from seismic events mean maximum values of vertical displacements, N-S and W-E extents were calculated. The mean maximum values of vertical displacements of the ground for each analysed pair of images range from - $70 \mathrm{~mm}$ to $-94 \mathrm{~mm}$. The highest mean value of maximum displacement, as an average of 8 out of 10 processed pairs of radar images was obtained for the seismic event with greatest magnitude (4.8). The mean maximum displacement has reached approx. $-9 \mathrm{~cm}(-94 \mathrm{~mm})$. The lowest mean value of maximum displacement $(-70 \mathrm{~mm})$ was obtained for the seismic event with the lowest magnitude (4.5). A linear relation (with $\mathrm{R}^{2}$ value of 0.977) was determined between magnitude of seismic event and mean maximum registered displacement (blue dashed line) (Fig. 3). On average the mean maximum value of vertical displacement increases by -7 to $-10 \mathrm{~mm}$ for 0.1 increase of tremor's magnitude (blue solid line). The mean extent of deformation areas ranges from $1.5 \mathrm{~km}$ to $1.9 \mathrm{~km}$ in the $\mathrm{W}-\mathrm{E}$ direction and from $1.8 \mathrm{~km}$ to $2.1 \mathrm{~km}$ in the N-S direction. In case of the extent of the deformation areas a similar linear relation with magnitude was obtained (blue solid line) (Fig. 4 and Fig. 5). A better fit was obtained for the $\mathrm{N}-\mathrm{S}$ component $\left(\mathrm{R}^{2}\right.$ equal to 0.978 ) than for the W-E one $\left(\mathrm{R}^{2}\right.$ equal to 0.894$)$ (blue dashed lines).

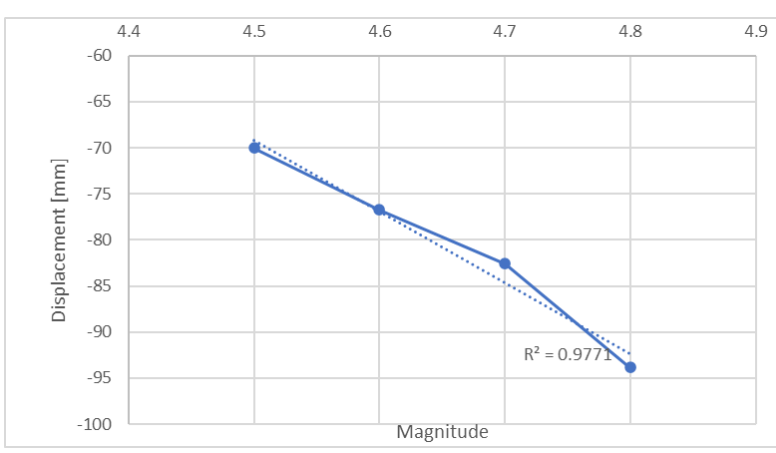

Figure 3. Graph of mean maximum vertical displacement and registered magnitude of seismic events

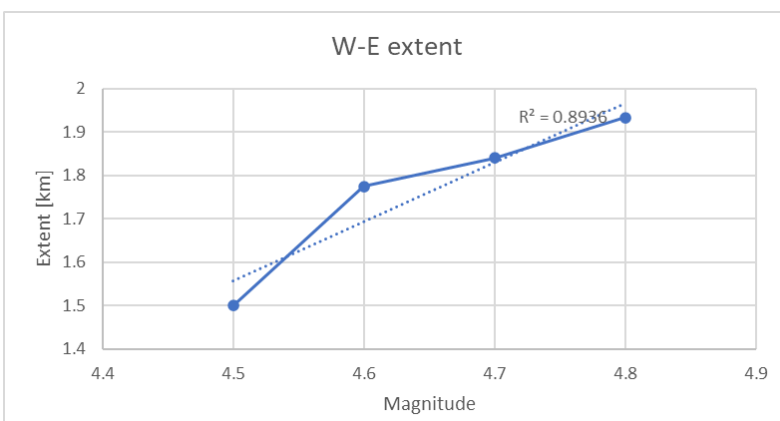

Figure 4. Graph of mean extent of deformation areas in W-E direction and registered magnitude of seismic events

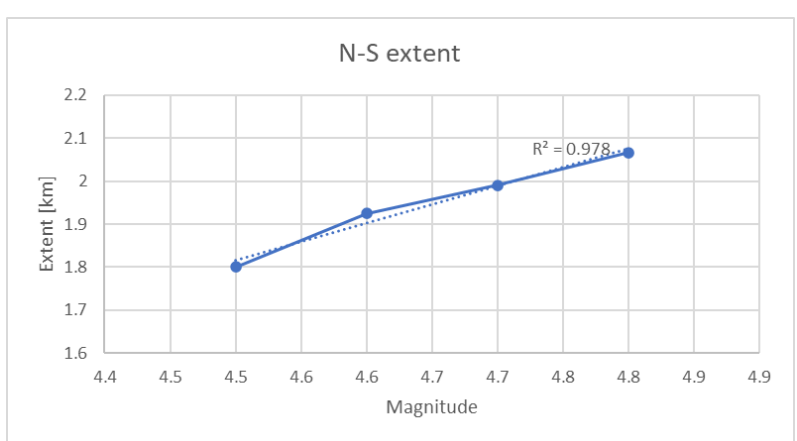

Figure 5. Graph of mean extent of deformation areas in N-S direction and registered magnitude of seismic events

Graphical representations (maps) of generalised deformation areas for each seismic events have been presented in figures 6 to 9 . The negative value of displacement indicates subsidence. The displacement maps have been made in ESRI ArcGIS software licensed to Wroclaw University of Science and Technology based on the results of calculations in the GMTSAR version 5.4.5 software. GIS spline interpolation function for optimised parameters of the method have been used to generate displacement maps for the four induced shocks: 16 December 2016 (Fig. 6), 7 December 2017 (Fig. 7), 26 December 2017 (Fig. 8) and 15 September 2018 (Fig. 9). The spatial extent of the subsidence zone was determined as the area of displacement greater than the value of $-10 \mathrm{~mm}$. 


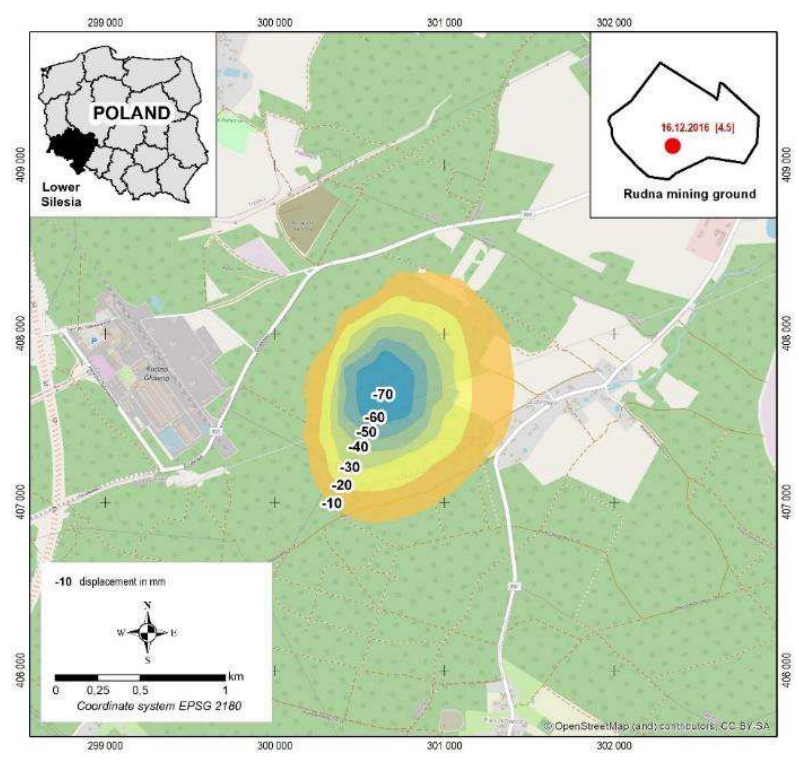

Figure 6. Map of the deformation resulting from the seismic event of 16 December 2016

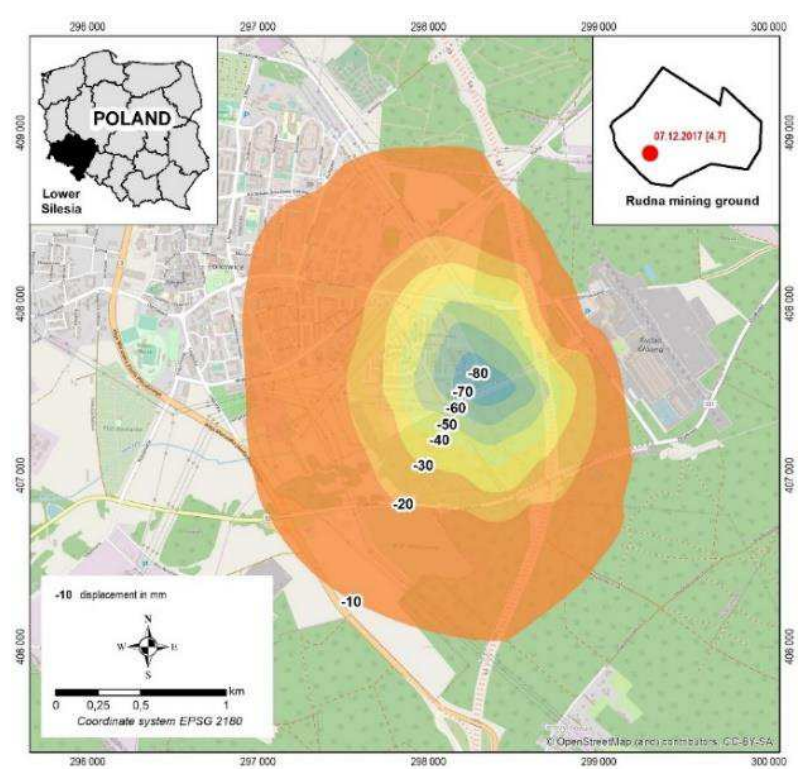

Figure 7. Map of the deformation resulting from the seismic event of 7 December 2017

The general shape and extent of surface deformations resulting from the analysed seismic events agree with the results of authors analysing other such tremors. For example, (Malinowska et al., 2017) obtained the following values for the seismic event of 29 November 2016 (magnitude 4.5), vertical displacement of -80 $\mathrm{mm}$, extent in the N-S direction $2.8 \mathrm{~km}$ and extent in the $\mathrm{W}-\mathrm{E}$ direction $1.7 \mathrm{~km}$, whereas (Milczarek 2019) determined the following values for the same tremor, vertical displacement of - $80 \mathrm{~mm}$, and extent of $2.7 \mathrm{~km}$ (in N-S direction) by $2.5 \mathrm{~km}$ (in W-E direction). Likewise, Hejmanowski et al. 2019 analysed the 7 December 2017 and 26 December 2017 seismic events and the maximum displacement value obtained for the first tremor $(-84 \mathrm{~mm})$ is similar to the mean maximum displacement value in this study $-83 \mathrm{~mm}$, whereas the one for the latter tremor is greater $(-116 \mathrm{~mm})$ than our findings $(-94 \mathrm{~mm})$. The extents obtained are similar. Studies of deformations caused by induced seismicity, presented in literature, usually referred to a single seismic event

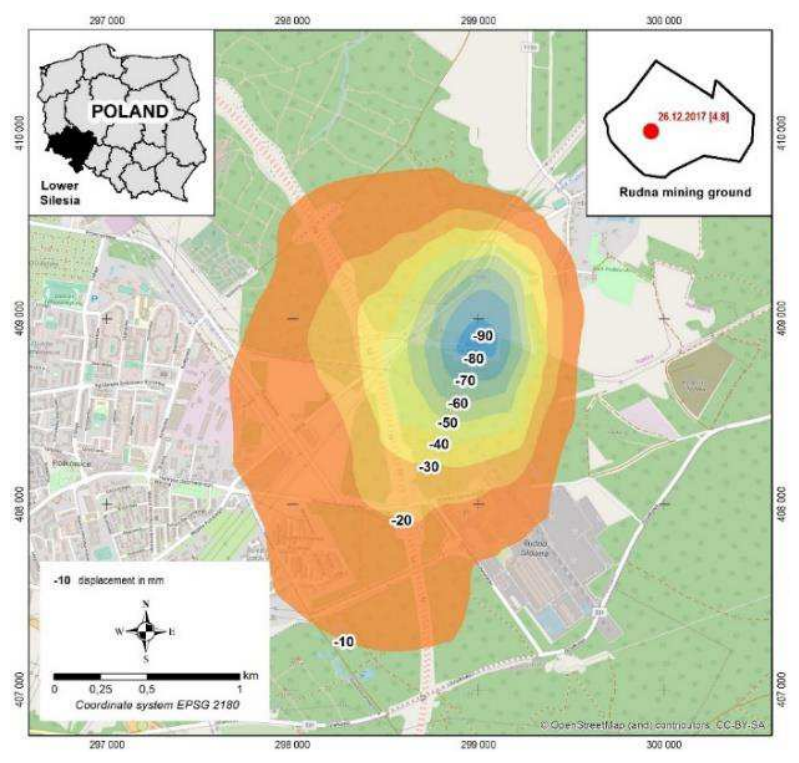

Figure 8. Map of the deformation resulting from the seismic event of 26 December 2017

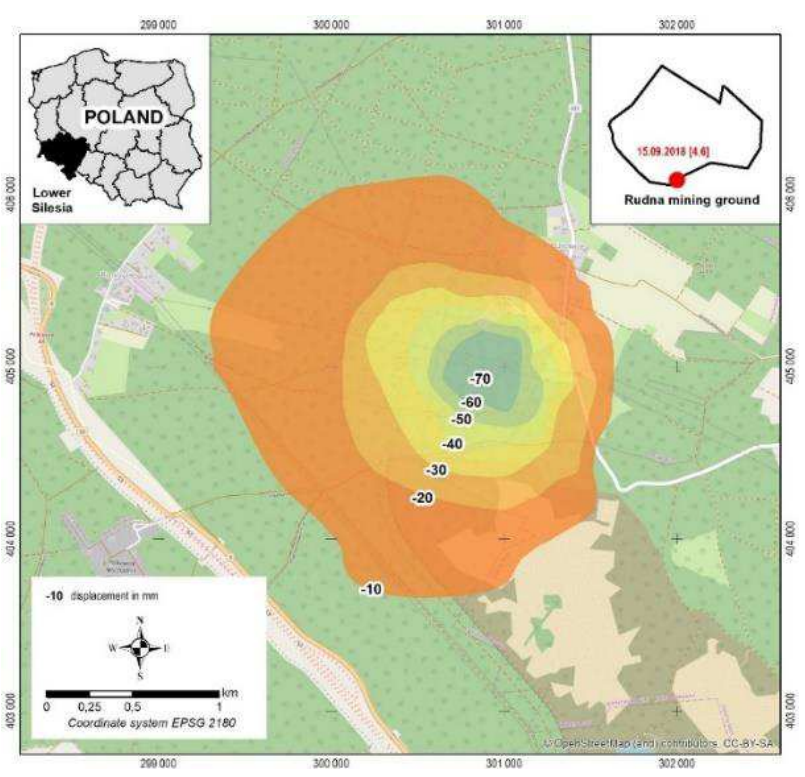

Figure 9. Map of the deformation resulting from the seismic event of 15 September 2018

and used smaller sets of data (image pairs). In this study we used a large number of image pairs to obtain a recurrent information on the geometry of deformation and also proved that there is a linear relationship between the size of the deformation area and magnitude of seismic event. In addition, we confronted our results with displacements received by other scientists who conducted research in this area. We have also confirmed that the DInSAR method can be successfully used to detect and to determine terrain surface deformation resulting from induced seismic event in mining grounds.

\section{CONCLUSION}

Nowadays, availability of satellite radar data and development of satellite radar interferometry processing techniques allows to study deformations caused by human induced seismicity through analyzing radar data collected prior and after such sudden and 
unexpected dynamic events. Four recent seismic tremors induced by underground copper ore mining were analysed. The selected tremors had magnitudes ranging from 4.5 to 4.8 . In the result of DInSAR processing of Sentinel-1 data, extent and vertical displacements were accurately determined for all of the analysed cases. The geometrical parameters of deformation areas were estimated as mean maximum values for 37 sets of image pairs, approx. 8 to 10 for each analysed case and acquired at temporal intervals of $6,12,18$ and 24 days. The obtained values indicate that mean maximum subsidence and mean maximum extent increase with the tremor magnitude and that for the investigated magnitudes this relationship is linear. The maximum values of vertical displacement vary from $-70 \mathrm{~mm}$ (for event with magnitude 4.5) to $-94 \mathrm{~mm}$ (for event with magnitude 4.8), whereas spatial extent varies from $1.5 \mathrm{~km}$ to $1.9 \mathrm{~km}$ in the W-E direction and $1.8 \mathrm{~km}$ to $2.1 \mathrm{~km}$ in the N-S direction. The exact values of ground surface deformations may only be determined based on ground levelling surveys. However, such geodetic measurements are very rarely carried out in location and in time that would allow to investigate effect of induced seismic event due to its unpredictable character. Application of DInSAR processing technique and analysis of a number of image pairs acquired prior and after such events provided information that allows to accurately estimate and map the resulting deformations.

\section{REFERENCES}

Albano, M., Polcari, M., Bignami, Ch., Moro, M., Saroli, M., Stramondo, S., 2017. Did Anthropogenic Activities Trigger the 3 April 2017 Mw 6.5 Botswana Earthquake. Remote Sensing, 9.

Barba, M., Tiampo, K.F., Samsonov, S.V., 2016. InSAR MSBAS Time-Series Analysis of Induced Seismicity in Colorado and Oklahoma. American Geophysical Union.

Bianchini, S., Raspini, F., Solari, L., Del Soldato, M., Ciampalini, A., Rosi, A., \& Casagli, N., 2018. From Picture to Movie: Twenty Years of Ground Deformation Recording Over Tuscany Region (Italy) With Satellite InSAR. Frontiers in Earth Science, 6, 177.

Butra, J., Dębkowski, R., Szpak, M., Kirej, M., 2017. Koncepcja eksploatacji złoża rud miedzi w węźle uskoków Rudna Główna i Biedrzychowa O/ZG Rudna KGHM Polska Miedź S.A. CUPRUM - Czasopismo Naukowo-Techniczne Górnictwa Rud, 2 (83), 29-38, (in Polish).

Ellsworth, W.L., 2013. Injection-Induced Earthquakes. Sience, 12,341 .

European-Mediterranean Seismological Centre database (a)https://www.emsc-csem.org (31 January 2020).

Fougler, G.R., Wilson, M.P., Gluyas, J.G., Julian, B.R., Davies, R.J., 2018. Global review of human-induced earthquakes. EarthScience Reviews 178: 438-514.

Graniczny, M., Kowalski, Z., Kowalski, P., Przyłucka, M., 2017. Satellite interferometry for ground deformation monitoring, the LGOM example. Biuletyn - PIG, 469,59-66.

Hejmanowski, R., Malinowska, A.A., Witkowski, W.T., Guzy, A., 2019. An Analysis Applying InSAR of Subsidence Caused by Nearby Mining-Induced Earthquakes. Geosciences, 9 (12).

Hooper, A., Bekaert, D., Spaans, K., \& Arıkan, M., 2012. Recent advances in SAR interferometry time series analysis for measuring crustal deformation. Tectonophysics, 514, 1-13.
Juncu, D., Arnadóttir, Th., Geirsson, H., Gudmundsson, G.B., Lund, B., Gunnarsson, G., Hooper, A., Hreinsdóttir, S., Michalczewska, K., 2018. Injection-induced surface deformation and seismicity at the Hellisheidi geothermal field, Iceland. Journal of Volcanology and Geothermal Research.

Kaszowska O., 2007. Wpływ podziemnej eksploatacji górniczej na powierzchnię terenu. Problemy ekologii, 11(1), (in Polish).

KGHM Polish Copper S.A. corporate website. www.kghm.com (20 January 2020).

KGHM Polish Copper S.A. internal team, 2012. Report: Aktywa górnicze KGHM Polska Miedz S.A. w rejonie LegnickoGłogowskiego Okręgu Miedziowego, (in Polish).

Kiersnowski, H. , Petecki, Z., 2017. Geology of the Zechstein basement of the Legnica-Głogów Copper District (LGOM) and its surroundings: a critical overview. Biuletyn Państwowego Instytutu Geologicznego, 468, 175-197, (in Polish with English abstract).

Krawczyk, A., Grzybek, R., 2018. An evaluation of processing InSAR Sentinel-1A/B data for correlation of mining subsidence with mining induced tremors in the Upper Silesian Coal Basin (Poland). E3S Web Conf., 26.

Loesch, E., Sagan, V., 2018. SBAS Analysis of Induced Ground Surface Deformation from Wastewater Injection in East Central Oklahoma, USA. Remote Sens., 10(2), 283.

Malinowska, A.A., Witkowski, W.T., Guzy, A., Hejmanowski, R., 2017. Study of dynamic displacement phenomena with the use of imaging radars from the Sentinel mission. Zeszyty Naukowe Instytutu Gospodarki Surowcami Mineralnymi $i$ Energia PAN ,101, 229-246.

Milczarek, W., 2019. Investigation of post inducted seismic deformation of the $2016 \mathrm{mw} 4.2$ Tarnowek Poland mining tremor based on DInSAR and SBAS methods. Acta Geodyn. Geomater., 16(2), 183-193.

Polish Geological Institute National Research Institute, www.pig.gov.pl (10 January 2020).

Popiołek, E., Ostrowski, J., Czaja, J., Mazur, J., 2001. The Impact of a Strong Mining Tremor on the Subsidence of the Area Surface in the Legnica-Glogow Copper Area. In Proceedings of the 10th FIG International Symposium on Deformation Measurements, International Federation of Surveyors, Orange, CA, USA, 19-22 March 2001, 77-80.

Rudziński, Ł., Mirek, K., Mirek, J., 2019. Rapid ground deformation corresponding to a mining-induced seismic event followed by a massive collapse. Natural Hazards, 96(1). 461471.

Sudoł, E., 2009. Using the leveling measurement in modeling of mining and geological parameters on LGOM area, Acta Sci. Pol., Geodesia et Descriptio Terrarum, 8(3), 13-22, (in Polish with English abstract).

Szczerbowski, Z., Jura, J., 2015. Mining induced seismic events and surface deformations monitored by GPS permanent stations. Acta Geodyn. Geomater., 12, 237-248. 
Thorpe, S., 2017. Time series analysis of surface deformation associated with fluid injection and induced seismicity in Timpson, Texas using DInSAR methods. Electronic Thesis and Dissertation Repository.

Yastika, P.E., Shimizu, N., 2016. Applications of DInSAR for Ground Surface Deformation Measurements-Case Studies of Subsidence Measurements and Deformation Detections Due to an Earthquake. The 37th West Japan Symposium on Rock Engineering 2016.

Zembaty Z., 2004. Rockburst induced ground motion - a comparative study. Soil Dynamics \& Earthquake Engineering, Vol. 24, No. 1, pp. 11-23.

Zembaty Z., 2010. The application of Eurocode 8 in the design of structures under the mine tremors. Budownictwo Czasopismo Techniczne (Civil Enginieering) (in Polish with English abstract). 


\section{APPENDIX A}

Shock of 16 December 2016 $07 / 12 / 2016$ and $19 / 12 / 2016$ 22 track

Shock of 7 December 2017 $29 / 11 / 2017$ and $11 / 12 / 2017$ 73 track

Shock of 26 December 2017 $23 / 12 / 2017$ and $04 / 01 / 2018$ 73 track

Shock of 15 September 2018 $04 / 09 / 2018$ and $16 / 09 / 2018$ 22 track
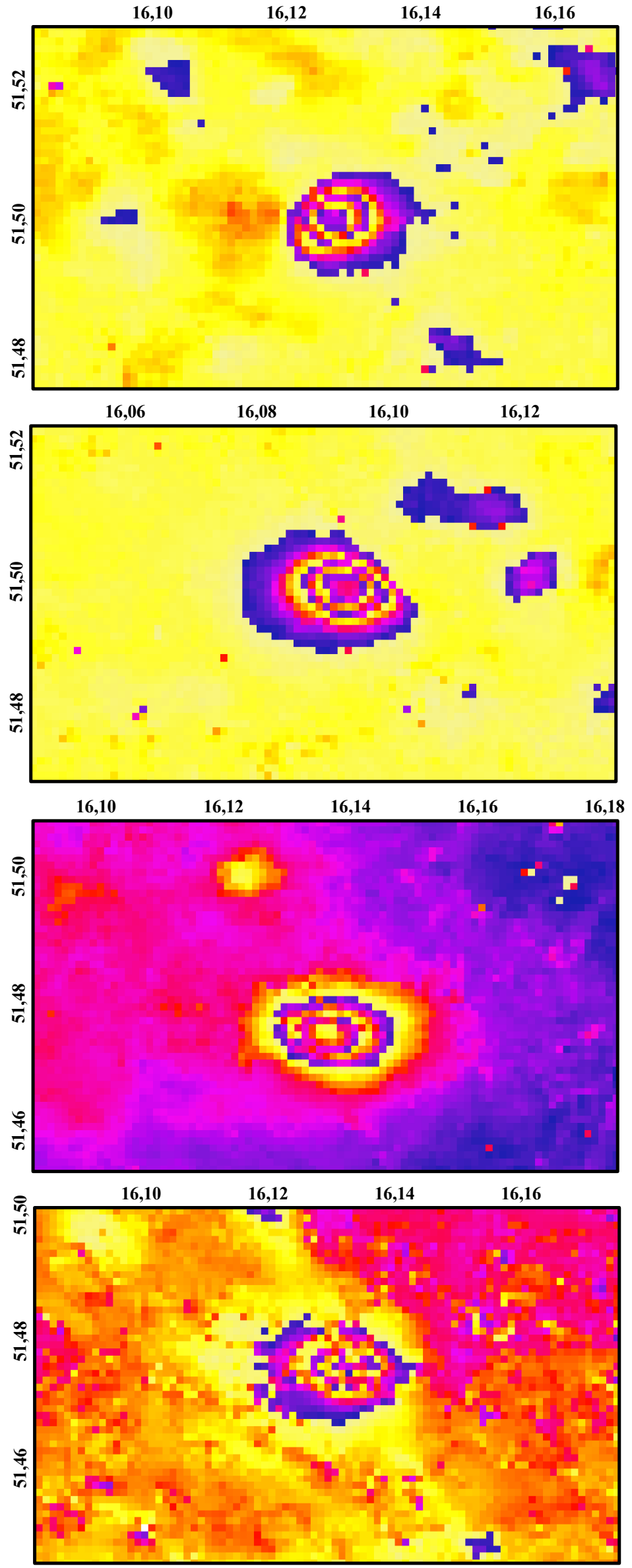

Phase [rad] 